\title{
How long does it take phentolamine to reverse adrenaline-induced vasoconstriction in the finger and hand? A prospective, randomized, blinded study: The Dalhousie project experimental phase
}

\author{
Trefor Nodwell MDCM, Don Lalonde BSc MSc MD FRCSC
}

T Nodwell, D Lalonde. How long does it take phentolamine to reverse adrenaline-induced vasoconstriction in the finger and hand? A prospective randomized blinded study: The Dalhousie project experimental phase. Can J Plast Surg 2003;11(4):187-190.

At the Dalhousie Plastic Surgery Alumni Reunion at the Atlantic Plastic Surgery meeting in Halifax, Nova Scotia, in September 2001, 22 subjects, including 18 certified hand surgeons, were injected with $1.8 \mathrm{~mL}$ of $2 \%$ lidocaine with $1: 100,000$ adrenaline in three places in one finger of each hand. One hour later, the same sites of one hand were injected with phentolamine ( $1 \mathrm{mg}$ in $1 \mathrm{~mL}$ ), and the other hand was injected with saline. Subjects were blinded as to which hand received the phentolamine. It took an average of $85 \mathrm{~min}$ for the adrenaline-injected fingers to return to normal colour after phentolamine injection. It took an average of $320 \mathrm{~min}$ for the adrenalineinjected fingers to return to normal colour after saline injection (no phentolamine). We also observed that lidocaine with adrenaline provided an average of $549 \mathrm{~min}$ of anesthesia in nonphentolamineinjected fingers. Phentolamine consistently and reliably reversed adrenaline-induced vasoconstriction in the finger

Key Words: Adrenaline; Epinephrine; Finger; Hand; Phentolamine
Combien faut-il de temps pour que la phentolamine annule une vasoconstriction causée par l'adrénaline dans le doigt et la main? Une étude prospective aléatoire en insu : Phase expérimentale du projet de Dalhousie
T he vasoconstrictive properties of adrenaline are used to decrease intraoperative bleeding in all areas of the body. Late 20th century dogma warning of the danger of adrenaline in the nose and ears has been refuted, and these anatomical sites are routinely infiltrated with adrenaline in clinical practice today.

In spite of a growing body of scientific evidence that low dose adrenaline $(1: 100,000)$ is safe in the fingers $(1-4)$, most medical schools and physicians still fear the use of adrenaline in elective surgery in the fingers and hand. This concern is mostly based on papers written in the late 19th to mid 20th centuries, when there were 21 reported cases of digital ischemia associated with adrenaline use (1). Most important, all of these reports were either written before the introduction of commercially available phentolamine or did not consider the use of phentolamine as an antagonist to reverse adrenalineinduced finger ischemia.

Numerous case reports beginning in 1969 document the successful use of phentolamine for the reversal of adrenalinemediated digital ischemia (5-16). These describe cases of accidental digital injection of high dose $(1: 1000)$ adrenaline with
À la rencontre des anciens de chirurgie plastique de Dalhousie qui avait lieu au congrès de chirurgie plastique de l'Atlantique à Halifax, en NouvelleÉcosse, en septembre 2001, 22 sujets, y compris 18 chirurgiens de la main certifiés, ont reçu une injection de $1,8 \mathrm{~mL}$ de lidocaine $2 \%$ et 1:100 000 d'adrénaline à trois endroits dans un doigt de chaque main. Une heure plus tard, on a injecté de la phentolamine $(1 \mathrm{mg}$ dans $1 \mathrm{~mL})$ dans les mêmes foyers d'une main, et une solution saline dans l'autre main. Les sujets ne savaient pas dans quelle main ils recevaient de la phentolamine. Il a fallu en moyenne 85 minutes pour que les doigts dans lesquels l'adrénaline avait été injectée retrou vent leur couleur normale après l'injection de phentolamine, tandis que les doigts dans lesquels on avait injecté de l'adrénaline n'ont retrouvé leur couleur normale qu'une moyenne de 320 minutes après l'injection de solution saline (sans phentolamine). De plus, la lidocaïne associée à l'adrénaline provoquait une anesthésie moyenne de 549 minutes dans les doigts dans lesquels on n'avait pas injecté de phentolamine. La phentolamine annulent avec constance et fiabilité la vasoconstriction du doigt provoquée par l'adrénaline.

autoinjector kits used to reverse insect bite-induced anaphylaxis. As these reports outline, phentolamine is the drug of choice for digital salvage in these situations. In addition, phentolamine has been the recommended treatment for the prevention of skin slough with inadvertent interstitial injection of high dose $(1: 100,000)$ adrenaline and noradrenaline since $1957(17,18)$.

As the clinical evidence mounts, demonstrating the safety of digital block with lidocaine and low dose adrenaline $(1: 100,000)$, more and more surgeons are using this compound in their practices. However, there have not been any studies in the literature that have examined the pharmacodynamic interaction of adrenaline and phentolamine in the finger.

The present study was conducted to determine the length of time required for phentolamine to reverse the clinically apparent vasoconstrictive effects of adrenaline in the finger. It represents the first phase of the Dalhousie project. The goal of the Dalhousie project is to examine the safety of adrenaline-induced vasoconstriction in elective hand surgery. 


\section{MATERIALS AND METHODS}

Twenty-two subjects were enrolled in the present study. The participants were all volunteers involved with Hand Surgery at Dalhousie University. The volunteer group comprised 18 plastic surgeons, two plastic surgery residents, one hand therapist and one registered nurse. They volunteered for injections after hearing a 20 min presentation on the risks and benefits of lidocaine, adrenaline and phentolamine in the finger at the Atlantic Plastic Surgery meeting in Halifax, Nova Scotia, in September 2002. Subjects were eligible to participate if they did not have a significant history of myocardial infarction, active coronary artery disease, finger ischemia, allergy to phentolamine or current pregnancy. The sample size was calculated based on the number (n) needed to detect a statistically significant difference in the means between the two groups. To detect a difference with a $\mathrm{P}$ value of 0.05 and power of $90 \%$, estimating the population mean difference (error) to be $30 \mathrm{~min}, 17$ subjects needed to be enrolled.

All subjects underwent digital block with lidocaine and adrenaline. At the subjects' discretion, either the long or the ring fingers of both hands were chosen. Both hands of each subject were marked and injected in three places: the volar distal palmar crease; the volar base of the proximal phalanx; and the volar base of the middle phalanx (Figure 1). Each spot was injected subcutaneously with $1.8 \mathrm{~mL}$ of Xylocaine 2\% (AstraZeneca Canada Inc, Ontario) with $1: 100,000$ adrenaline (one dental cartridge) using a 30-gauge needle on a dental syringe, for a total of $10.8 \mathrm{~mL} \quad(5.4 \mathrm{~mL}$ per hand). The time was documented.

Each hand was injected in three sites with $1.8 \mathrm{~mL}$ of $2 \%$ lidocaine with 1:100,000 adrenaline (Figure 1). One hour later each of the three sites of one hand were injected with $1 \mathrm{mg}(1 \mathrm{~mL})$ of phentolamine, and the three sites on the other hand were injected with $1 \mathrm{~mL}$ of saline.

One hour later, each subject had the same three places reinjected in both hands. This time, the right and left hands were randomized to receive three injections of phentolamine $1 \mathrm{~mL}$ of $1 \mathrm{mg} / \mathrm{mL}$ in one hand and three injections of $1 \mathrm{~mL}$ of normal saline in the other hand. Subjects were blinded as to which hand received the phentolamine and which hand received the saline. Thus, participants acted as their own blinded controls. The time was documented.

Each subject was given verbal and written instructions to observe for the return of normal volar colour and normal fingertip sensation. The results were returned to the primary investigator and any adverse reactions were documented.

\section{RESULTS}

It took an average of $85 \mathrm{~min}$ (mean $84.9 \pm 43.0 \mathrm{~min}$ ) for the adrenaline-injected fingers to return to the same colour as the other fingers after the injection of phentolamine (Table 1). It took an average of 319 min (mean $318 \pm 127 \mathrm{~min}$ ) for the adrenaline-injected fingers to return to the same colour as the other fingers after the injection of saline (Table 1). The Student's $t$ test of the mean difference was equal to zero $(t=9.25, \mathrm{P}=0.00)$. The difference in time to return to normal colour in the saline and phentolamine groups was $234 \mathrm{~min}$ (CI 95\% 181.2 to 286.4).

Subjectively normal sensation returned to the fingertips in an average of $120 \mathrm{~min}$ after injection of phentolamine (mean $120.2 \pm 84.7 \mathrm{~min}$ ) (Table 2). This contrasts with the average of $549 \mathrm{~min}$ for the saline injected side (mean $548.9 \pm 113.3 \mathrm{~min}$ ). The Student's $t$ test of the mean difference was equal to zero $(t=18.18, \mathrm{P}=0.00)$. The difference in time to return to normal

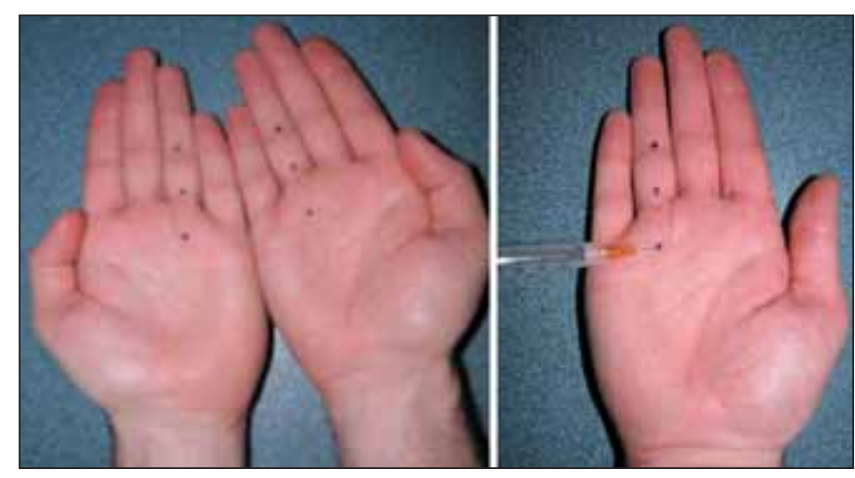

Figure 1) Each hand was injected in three sites with $1.8 \mathrm{~mL}$ of $2 \%$ lidocaine with 1:100,000 adrenaline. One hour later, each of the three sites of one hand were injected with $1 \mathrm{mg}(1 \mathrm{~mL})$ of phentolamine, and the three sites on the other hand were injected with $1 \mathrm{~mL}$ of saline

sensation in the saline and phentolamine groups was $429 \mathrm{~min}$ (CI 95\% 379.6 to 477.7).

There were no instances of digital loss for either arm of the study. Interestingly, although adrenaline induced digital pallor, all subjects' fingertips had evidence of blood flow, with nail bed capillary refill at all times.

The reported adverse reactions were (number of instances): nausea and presyncope after first injection (two); temporary, bilateral hand pallor and blue discoloration (one); palpitations or tremulousness (two) after first injection for $30 \mathrm{~min}$ to $45 \mathrm{~min}$; palpitations (one - different subject) after phentolamine; hyperemia and/or pruritis locally around phentolamine injection sites (two); prolonged numbness (several hours) to adjacent noninjected digit on phentolamine side (one); palmar bruising (one) saline side and (one) phentolamine side; dull forearm ache (one) for $4 \mathrm{~h}$ after saline injection; and pain on passive and active extension of injected digits lasting several days (three).

\section{DISCUSSION}

In the present study, we injected three finger sites of both hands of subjects with lidocaine with 1:100,000 (low dose) adrenaline. One hour later, one of the blinded hands received $1 \mathrm{mg}$ injections of phentolamine in the same three sites. The average time to return of the finger to normal colour after phentolamine injection was $85 \mathrm{~min}$. The opposite blinded hands received saline instead of phentolamine. Those hands (adrenaline without phentolamine) averaged $320 \mathrm{~min}$ before a return to normal colour after injection of the saline. Phentolamine reliably reversed the vasoconstrictive effect of adrenaline in all fingers in a predictable amount of time.

It was also observed that although all subjects underwent colour changes in the adrenaline-injected areas of the finger, capillary refill remained present in all of the subjects' nail beds throughout the period of adrenaline effect. In other words, we observed decreased but not absent finger blood flow with $5.6 \mathrm{~mL}$ of adrenaline 1:100,000 injected into the fingers.

We chose to inject the amount of lidocaine/adrenaline into the finger sites that we did because that amount of local anesthetic in those sites provides more than adequate anesthesia and adrenaline-induced hemostasis to perform Dupuytren's palmar fasciectomy, zone 2 flexor tendon repair and tenolysis in the clinical setting under local anesthetic without a tourniquet. 
TABLE 1

Time to return to normal colour in adrenaline-injected finger after second injection of phentolamine or saline

\begin{tabular}{|c|c|c|c|}
\hline $\begin{array}{l}\text { Name, } \\
\text { occupation }\end{array}$ & Digit & $\begin{array}{c}\text { Time to normal } \\
\text { colour return after } \\
\text { phentolamine injection } \\
\text { (min) }\end{array}$ & $\begin{array}{c}\text { Time to normal } \\
\text { colour return after } \\
\text { saline injection } \\
\text { (min) }\end{array}$ \\
\hline \multirow{2}{*}{$\begin{array}{l}\text { Dr D Lalonde, } \\
\text { surgeon }\end{array}$} & $\mathrm{R}$ long & 40 & \\
\hline & L long & & 490 \\
\hline \multirow{2}{*}{$\begin{array}{l}\text { S Kean, } \\
\text { hand therapist }\end{array}$} & $\mathrm{R}$ ring & & 555 \\
\hline & $L$ ring & 91 & \\
\hline \multirow{2}{*}{$\begin{array}{l}\text { Dr G Sparkes, } \\
\text { surgeon }\end{array}$} & $\mathrm{R}$ long & 65 & \\
\hline & L long & & 385 \\
\hline \multirow{2}{*}{$\begin{array}{l}\text { J Lalonde, } \\
\text { RN }\end{array}$} & $\mathrm{R}$ long & & 485 \\
\hline & L long & 70 & \\
\hline \multirow{2}{*}{$\begin{array}{l}\text { Dr J Obrien, } \\
\text { surgeon }\end{array}$} & $\mathrm{R}$ long & 230 & \\
\hline & L long & & 530 \\
\hline \multirow{2}{*}{$\begin{array}{l}\text { Dr W Parkhill, } \\
\text { surgeon }\end{array}$} & $\mathrm{R}$ long & 105 & \\
\hline & L long & & 405 \\
\hline \multirow{2}{*}{$\begin{array}{l}\text { Dr B Miller, } \\
\text { resident }\end{array}$} & $\mathrm{R}$ long & & 134 \\
\hline & L long & 68 & \\
\hline \multirow{2}{*}{$\begin{array}{l}\text { Dr D Hayden, } \\
\text { surgeon }\end{array}$} & $\mathrm{R}$ long & & 300 \\
\hline & L long & 90 & \\
\hline \multirow{2}{*}{$\begin{array}{l}\text { Dr R French, } \\
\text { surgeon }\end{array}$} & $\mathrm{R}$ long & 165 & \\
\hline & L long & & 300 \\
\hline \multirow{2}{*}{$\begin{array}{l}\text { Dr G Mac Lean, } \\
\text { surgeon }\end{array}$} & $\mathrm{R}$ long & 98 & \\
\hline & L long & & 458 \\
\hline \multirow{2}{*}{$\begin{array}{l}\text { Dr B Cook, } \\
\text { surgeon }\end{array}$} & $\mathrm{R}$ ring & & 330 \\
\hline & $\mathrm{L}$ ring & 100 & \\
\hline \multirow{2}{*}{$\begin{array}{l}\text { Dr C Thompson, } \\
\text { resident }\end{array}$} & $\mathrm{R}$ long & 70 & \\
\hline & L long & & 242 \\
\hline \multirow{2}{*}{$\begin{array}{l}\text { Dr S Morris, } \\
\text { surgeon }\end{array}$} & $\mathrm{R}$ long & 53 & \\
\hline & L long & & 373 \\
\hline \multirow{2}{*}{$\begin{array}{l}\text { Dr M Brennan, } \\
\text { surgeon }\end{array}$} & $\mathrm{R}$ long & 57 & \\
\hline & L long & & 293 \\
\hline \multirow{2}{*}{$\begin{array}{l}\text { Dr G Caputy, } \\
\text { surgeon }\end{array}$} & $\mathrm{R}$ long & 86 & \\
\hline & L long & & 206 \\
\hline \multirow{2}{*}{$\begin{array}{l}\text { Dr D Humphreys, } \\
\text { surgeon }\end{array}$} & $\mathrm{R}$ long & & 323 \\
\hline & L long & 95 & \\
\hline \multirow{2}{*}{$\begin{array}{l}\text { Dr A Rideout, } \\
\text { surgeon }\end{array}$} & $\mathrm{R}$ long & 57 & \\
\hline & L long & & 212 \\
\hline \multirow{2}{*}{$\begin{array}{l}\text { Dr M Oja, } \\
\text { surgeon }\end{array}$} & $\mathrm{R}$ long & & 247 \\
\hline & L long & 69 & \\
\hline \multirow{2}{*}{$\begin{array}{l}\text { Dr D Jewer, } \\
\text { surgeon }\end{array}$} & $\mathrm{R}$ long & & 195 \\
\hline & L long & 40 & \\
\hline \multirow{2}{*}{$\begin{array}{l}\text { Dr F Watkins, } \\
\text { surgeon }\end{array}$} & $\mathrm{R}$ long & 45 & \\
\hline & L long & & 120 \\
\hline \multirow{2}{*}{$\begin{array}{l}\text { Dr K Bush, } \\
\text { surgeon }\end{array}$} & $\mathrm{R}$ long & 68 & \\
\hline & L long & & 243 \\
\hline \multirow{2}{*}{$\begin{array}{l}\text { Dr L Sigurdson, } \\
\text { surgeon }\end{array}$} & $\mathrm{R}$ long & 106 & \\
\hline & L long & & 186 \\
\hline
\end{tabular}

L Left; R Right

Phentolamine is a competitive antagonist of alpha-receptors. As such, it has been used as an effective antihypertensive, in particular as an intravenous drug for preoperative blood pressure control in patients undergoing excision of pheochromocytoma. It also effectively reduces skin slough after the interstitial infusion of alpha-agonists. Manufacturers recommend a dosage of phentolamine of $3 \mathrm{mg}$ to $5 \mathrm{mg}$ intravenously to lower blood pressure (19). To reverse subcutaneous adrenaline-induced vasospasm, the manufacturers recommend $5 \mathrm{mg}$ to $10 \mathrm{mg}$ of phentolamine in $10 \mathrm{~mL}$ of saline to be infiltrated subcutaneously where the adrenaline was infiltrated
TABLE 2

Time to return to normal sensation in adrenaline-injected fingertip after second injection with phentolamine or saline

\begin{tabular}{|c|c|c|c|}
\hline $\begin{array}{l}\text { Name, } \\
\text { occupation }\end{array}$ & Digit & $\begin{array}{l}\text { Time to normal } \\
\text { finger tip sensation } \\
\text { after phentolamine } \\
\text { (min) }\end{array}$ & $\begin{array}{c}\text { Time to } \\
\text { normal finger tip } \\
\text { sensation after saline } \\
\text { (min) }\end{array}$ \\
\hline \multirow{2}{*}{$\begin{array}{l}\text { Dr D Lalonde, } \\
\text { surgeon }\end{array}$} & R long & 300 & \\
\hline & L long & & 820 \\
\hline \multirow{2}{*}{$\begin{array}{l}\text { S Kean, } \\
\text { hand therapist }\end{array}$} & $\mathrm{R}$ ring & & 685 \\
\hline & L ring & 98 & \\
\hline \multirow{2}{*}{$\begin{array}{l}\text { Dr G Sparkes, } \\
\text { surgeon }\end{array}$} & R long & 140 & \\
\hline & L long & & 515 \\
\hline \multirow{2}{*}{$\begin{array}{l}\text { J Lalonde, } \\
\text { RN }\end{array}$} & R long & & 725 \\
\hline & L long & 125 & \\
\hline \multirow{2}{*}{$\begin{array}{l}\text { Dr J Obrien, } \\
\text { surgeon }\end{array}$} & R long & 290 & \\
\hline & L long & & 590 \\
\hline \multirow{2}{*}{$\begin{array}{l}\text { Dr W Parkhill, } \\
\text { surgeon }\end{array}$} & R long & 75 & \\
\hline & L long & & 675 \\
\hline \multirow{2}{*}{$\begin{array}{c}\text { Dr B Miller, } \\
\text { resident }\end{array}$} & R long & & 624 \\
\hline & L long & 110 & \\
\hline \multirow{2}{*}{$\begin{array}{l}\text { Dr D Hayden, } \\
\text { surgeon }\end{array}$} & R long & & 445 \\
\hline & L long & 120 & \\
\hline \multirow{2}{*}{$\begin{array}{l}\text { Dr R French, } \\
\text { surgeon }\end{array}$} & $\mathrm{R}$ long & & 580 \\
\hline & L long & 345 & \\
\hline \multirow{2}{*}{$\begin{array}{l}\text { Dr G Mac Lean, } \\
\text { surgeon }\end{array}$} & R long & 53 & \\
\hline & L long & & 578 \\
\hline \multirow{2}{*}{$\begin{array}{c}\text { Dr B Cook, } \\
\text { surgeon }\end{array}$} & $\mathrm{R}$ ring & & 490 \\
\hline & $\mathrm{L}$ ring & 160 & \\
\hline \multirow{2}{*}{$\begin{array}{l}\text { Dr C Thompson, } \\
\text { resident }\end{array}$} & R long & 40 & \\
\hline & L long & & 508 \\
\hline \multirow{2}{*}{$\begin{array}{l}\text { Dr S Morris, } \\
\text { surgeon }\end{array}$} & R long & 68 & \\
\hline & L long & & 523 \\
\hline \multirow{2}{*}{$\begin{array}{l}\text { Dr M Brennan, } \\
\text { surgeon }\end{array}$} & R long & 67 & \\
\hline & L long & & 667 \\
\hline \multirow{2}{*}{$\begin{array}{l}\text { Dr G Caputy, } \\
\text { surgeon }\end{array}$} & R long & 41 & \\
\hline & L long & & 416 \\
\hline \multirow{2}{*}{$\begin{array}{l}\text { Dr D Humphreys, } \\
\text { surgeon }\end{array}$} & R long & & 433 \\
\hline & L long & 128 & \\
\hline \multirow{2}{*}{$\begin{array}{l}\text { Dr A Rideout, } \\
\text { surgeon }\end{array}$} & R long & 62 & \\
\hline & L long & & 477 \\
\hline \multirow{2}{*}{$\begin{array}{l}\text { Dr M Oja, } \\
\text { surgeon }\end{array}$} & R long & & 447 \\
\hline & L long & 70 & \\
\hline \multirow{2}{*}{$\begin{array}{l}\text { Dr D Jewer, } \\
\text { surgeon }\end{array}$} & R long & & 428 \\
\hline & L long & 78 & \\
\hline \multirow{2}{*}{$\begin{array}{l}\text { Dr F Watkins, } \\
\text { surgeon }\end{array}$} & R long & 120 & \\
\hline & L long & & 570 \\
\hline \multirow{2}{*}{$\begin{array}{l}\text { Dr K Bush, } \\
\text { surgeon }\end{array}$} & R long & 68 & \\
\hline & L long & & 393 \\
\hline \multirow{2}{*}{$\begin{array}{l}\text { Dr L Sigurdson, } \\
\text { surgeon }\end{array}$} & R long & 86 & \\
\hline & L long & & 486 \\
\hline
\end{tabular}

L Left; R Right

(19). We chose the higher $1 \mathrm{mg} / \mathrm{mL}$ concentration of phentolamine in the present study. A total of $3 \mathrm{mg}(3 \mathrm{~mL})$ of phentolamine injected subcutaneously adequately reversed the adrenaline vasoconstriction in the fingers in this study. The low blood flow state of the fingers into which the phentolamine was injected delayed its systemic absorption, just as systemic absorption of subcutaneous lidocaine is delayed with adrenaline. We did not examine the blood pressure of the subjects to see if the $3 \mathrm{mg}$ of slowly absorbed, subcutaneously injected phentolamine changed their blood pressure. 


\section{$\frac{\text { MORPHINE }}{\text { NALOXONE }}=\frac{\text { ADRENALINE }}{\text { PHENTOLAMINE }}$}

Figure 2) Analogy of the relationship of four drugs

Increasing numbers of surgeons are performing hand surgery under local anesthesia with adrenaline-induced hemostasis rather than under general or local anesthesia with tourniquetinduced hemostasis $(2-4,20)$. The proposed benefits include the following:

- the risks of general anesthesia are avoided, particularly in elderly Dupuytren's patients with medical problems;

- local anesthesia is more efficient and convenient than general anesthesia;

- avoiding the forearm tourniquet with local anesthesia increases the range and comfort of the number of operations that can be conducted under local anesthetic;

- intraoperative active range of motion can be assessed without the pain and the hurry induced by forearm tourniquet in flexor tendon tenolysis and flexor tendon repair; and

- gapping and cruciate pulley inhibition of active range of motion can be seen and resolved intraoperatively in zone 2 flexor tendon repair.

\section{REFERENCES}

1. Denkler K. A comprehensive review of epinephrine in the finger: To do or not to do. Plast Reconstr Surg 2001;108:114-24.

2. Sylaidis P, Logan A. Digital blocks with adrenaline. An old dogma refuted. J Hand Surg [Br] 1998;23:17-9.

3. Wilhelmi BJ, Blackwell SJ, Miller J, Mancoll JS, Phillips LG. Epinephrine in digital blocks: Revisited. Ann Plast Surg 1998:41:410-4.

4. Wilhelmi BJ, Blackwell SJ, Miller JH, et al. Do not use epinephrine in digital blocks: Myth or truth? Plast Reconstr Surg 2001;107:393-7.

5. Jordan LK. An unusual case of digital ischemia. N C Med J 1969;30:418-9.

6. Maguire WM, Reisdorff EJ, Smith D, Wiegenstein JG. Epinephrineinduced vasospasm reversed by phentolamine digital block. Am J Emerg Med 1990;8:46-7.

7. Markovchick V, Burkhart KK. The reversal of the ischemic effects of epinephrine on a finger with local injections of phentolamine. J Emerg Med 1991;9:323-4.

8. Burkhart KK. The reversal of the ischemic effects of epinephrine on a finger with local injections of phentolamine. J Emerg Med 1992;10:496

9. McCauley WA, Gerace RV, Scilley C. Treatment of accidental digital injection of epinephrine. Ann Emerg Med 1991;20:665-8.

10. Mol CJ, Gaver J. A 39-year-old nurse with accidental discharge of an epinephrine autoinjector into the left index finger. J Emerg Nurs 1992;18:306-7.

11. Hinterberger JW, Kintzi HE. Phentolamine reversal of epinephrine-
The main concern of using adrenaline-induced hemostasis in hand surgery is the possibility of infarcting a finger. Surgeons doing elective hand surgery with adrenaline are using low dose $(1: 100,000)$ adrenaline. There are many reports of phentolamine successfully reversing accidental high dose (1:1000) adrenaline finger ischemia (5-15). Most important, there is not one documented case of adrenaline-induced finger infarction in which phentolamine was used or considered in the world literature (1). All of the existing antiadrenaline literature is either older than the introduction of commercially available phentolamine or has not considered the use of phentolamine as an antidote for adrenaline-induced finger ischemia in the reported cases.

In spite of the fact that morphine is potentially lethal in all patients, it is used routinely in elective surgery because safe dosage limits are observed, and naloxone is available as an antidote if required. Adrenaline is capable of infarcting fingers. However, if used in an appropriately low dosage in fingers without vascular insufficiency, and with the knowledge that there is an appropriate antidote in the form of phentolamine, it too may be used routinely someday in elective surgery (Figure 2).

It was also interesting that we observed that lidocaine with adrenaline provided an average of 549 min of anesthesia in nonphentolamine-injected fingers. This is a significant amount of time for postoperative pain relief.

\section{CONCLUSION}

Phentolamine was found to consistently and reliably reverse adrenaline-induced vasoconstriction in an average of $85 \mathrm{~min}$ in the finger.

induced digital vasospasm. How to save an ischemic finger. Arch Fam Med 1994;3:193-5.

12. Claudy FR. Pertinent medical intelligence: Accidental digital injection of epinephrine. Md Med J 1995;44:292-3.

13. McGovern SJ. Treatment of accidental digital injection of adrenaline from an auto-injector device. J Accid Emerg Med 1997;14:379-80.

14. Kostakoglu N, Kayikcioglu A. Late arterial insufficiency in a toe-tofinger transplantation following infiltration anesthesia with articaine plus epinephrine during septorhinoplasty. Plast Reconstr Surg 1998;101:1146.

15. Barkhordarian AR, Wakelin SH, Paes TR. Accidental digital injection of adrenaline from an autoinjector device. $\mathrm{Br} \mathrm{J}$ Dermatol 2000;143:1359.

16. Murali KS, Nayeem N. Accidental digital injection of adrenaline from an autoinjector device. J Accid Emerg Med 1998;15:287.

17. Zucker G. Use of phentolamine to prevent necrosis due to levarterenol. JAMA 1957;163:1477-9.

18. Berben JY, Bryant MF, Howard JM. Etiology and prevention of slough produced by L-norepinephrine (levophed). Ann Surg 1957;146:1016-20.

19. Canadian Pharmacists Association Compendium of Pharmaceuticals and Specialties 2000:1405.

20. Denkler K. Dupuytren's fascietomies in 60 consecutive digits using lidocaine with epinephrine and no tourniquet. Plas Reconstr Surg. (In press). 